\title{
COMPARISON OF PAIN SCORE IN OSTEOARTHRITIS PATIENTS TREATED WITH A COMBINATION OF DIACEREIN AND MELOXICAM AND MELOXICAM ALONE
}

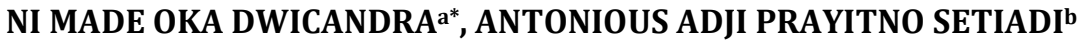 \\ aPharmacy Department, Institute of Health Sciences Medika Persada Bali, Denpasar, Bali, Indonesia, bDepartement of Clinical Pharmacy, \\ Pharmacy Faculty, University of Surabaya, Surabaya, Jawa Timur, Indonesia \\ Email: okadwicandra@gmail.com \\ Received: 12 Feb 2017 Revised and Accepted: 20 Apr 2017
}

\begin{abstract}
Objective: Osteoarthritis $(\mathrm{OA})$ is a progressive chronic disease with the loss of articular cartilage. In managing OA, inadequate pain relief (IPR) often occurs, particularly with a single non steroidal anti-inflammatory drugs (NSAIDs) therapy. In this research, pain outcome of OA patients
\end{abstract} treated with a combination of diacerein and meloxicam vs meloxicam alone was evaluated.

Methods: This research was conducted at rumah sakit umum daerah (RSUD) Dr. Mohammad Soewandhie Surabaya by using randomized controlled trial (RCT) design. Pain outcome was evaluated by pain intensity and area under the curve (AUC) of pain score in week $0-4^{\text {th }}$.

Results: There were a significantly different $(\mathrm{p}<0.05)$ in pain intensity seen in $3^{\text {rd }}$ and $4^{\text {th }}$ weeks after treated with a combination of diacerein and meloxicam, and with meloxicam only. However, there were no different in AUC pain score between combination and single therapy.

Conclusion: Combination therapy of diacerein and meloxicam was more effective than meloxicam alone. A significant effect of a combination therapy of diacerein and meloxicam occurred at $3^{\text {rd }}$ weeks. The prolong study in order to get the differences in AUC pain score are needed.

Keywords: Osteoarthritis, Diacerein, Meloxicam, Pain intensity

(C) 2017 The Authors. Published by Innovare Academic Sciences Pvt Ltd. This is an open access article under the CC BY license (http://creativecommons.org/licenses/by/4.0/) DOI: http://dx.doi.org/10.22159/ijpps.2017v9i6.17671

\section{INTRODUCTION}

Osteoarthritis $(\mathrm{OA})$ is a progressive chronic disease that was characterized by loss of articular cartilage [1]. World Health Organization data showed that $\mathrm{OA}$ is still one of the ten most diseases that caused disability in developed countries. Prevalence of radiological knee $\mathrm{OA}$ in Indonesia was $15.5 \%$ in men and $12.7 \%$ in women between 40-60 y of age [2].

Osteteoarthritic pain is a chronic pain. Its remission for longer period is difficult [3]. Osteoarthritis and pain symptom experienced by patients have bad effects. Walking limitations have an impact on activities of daily living, which $11 \%$ of patients need assistance to do personal care [1]. Osteoarthritis patients also have limitations to work [4]. A disability that occurs in OA patients is associated with greater depression [5]. However, in its management, inadequate pain relief (IPR) was occurred in $54-64 \%$ of patients. Satisfaction and quality of life become worse because of IPR [6-8].

Among the study of OA therapy, non steroidal anti-inflammatory drugs (NSAIDs) are the most widely prescribed medication [6-8], but they often cause a dissatisfaction in the treatment of pain [9]. The inability of NSAIDs in overcoming the pain can be caused by the analgesic ceiling effect. In addition, $\mathrm{OA}$ is a complex process involving a variety of mechanisms [9]. The combination of analgesics that works by different mechanism may lead to a synergistic effect in the treatment of OA $[10,11]$. Non steroidal anti-inflammatory drugs also do not affect the underlying pathogenesis of the disease [12], so they have a minimal role in modifying the course of the disease and improve the quality of life.

A combination drug that can be offered to overcome $\mathrm{OA}$ is diacerein and meloxicam. Diacerein is an interleukin 1(IL-1) inhibitor developed for the treatment of OA. Diacerein has efficacy in terms of functional manifestations and structural components of OA [13-15]. It plays an important role in cartilage degradation and stimulation of nociceptive pathways. This mediator shows potent bioactivity in inhibiting synthesis of extracellular matrix (ECM), promoting cartilage damage, and suppressing the expression of an important component of ECM in chondrocytes [16].
Although diacerein can contribute to overcoming the problem of OA, some studies are still debating its benefit. Several randomized controlled trials (RCTs) and meta-analysis studies showed the benefits of diacerein in the treatment of OA and others studies in the Cochrane library declared the absence of significant benefit of diacerein [13, 17-22]. Diacerein was reported having slow-acting properties. The long onset of diacerein cause pain management with diacerein must be combined with other analgesics, such as NSAIDs during the first month of treatment [14]. One of the NSAIDs that can be used is meloxicam that showed benefit in overcoming the pain of $\mathrm{OA}$ and rheumathoid disorder [23-26]. Meloxicam has a long halflife $(20-24 \mathrm{~h})$ so the using frequency was lower and easier for patients [27]. Based on the above, pain outcomes of OA patients receiving combination therapy of diacerein and meloxicam, and meloxicam alone were compared in this study.

\section{MATERIALS AND METHODS}

Study design

This was an open-label, RCT study. The study was conducted during the period January 2016-March 2016 at rumah sakit umum daerah (RSUD) Dr. Mohammad Soewandhie Surabaya. The patient was provided written informed consent. The study was approved by Badan Koordinasi Pendidikan RSUD Dr. Mohammad Soewandhie Surabaya and Badan Kesatuan Bangsa, Politik, dan Perlindungan Masyarakat Kota Surabaya with approval number 070/2554/436.7.8/2016. The consecutive sampling method was used to get participant.

Before intervention was started, screening visit was conducted to determine who will be included in the randomization. At the time of screening, washout was conducted for the analgesic that was used by patients. The washout period was conducted over $5 \times \mathrm{t}^{1} \frac{1}{2}$ of the drug. If patients experienced pain during the washout period, the patients would be given rescue medication (paracetamol $500 \mathrm{mg}$, maximum $4 \mathrm{~g} / \mathrm{d}$ ). After a washout period, and the patient experienced pain at least $24 \mathrm{~h}$ with scale $\geq 4$, randomization was conducted with blocked randomization method.

Participants in the study were divided into two groups, to receive the combination of diacerein (Artoflam $囚) 50 \mathrm{mg}$ once daily and 
meloxicam $15 \mathrm{mg}$ once daily or to receive meloxicam $15 \mathrm{mg}$ once daily. Drug administration was conducted for $4 \mathrm{w}$. Follow-up was done every week. Patients were asked to record date and a missed dose, other drugs taken, and changes in the drugs taken. Patients were asked to return the blister of drugs that have been taken and the rest of the drug (both drugs from our study or other drugs consumed by the participant).

Compliance was calculated by comparing the actual amount of drug taken with drugs should be taken during the treatment period. Patients who missed $>20 \%$ of the drugs were categorized as noncompliant. Patients were discontinued from the study if there were any violation in the criteria of the study, non-compliance with the study protocol, or the incidence of severe side effects.

\section{Patient}

The population was outpatients of the orthopedy clinic in RSUD Dr. Mohammad Soewandhie Surabaya. Patients were eligible for the study if they were diagnosed with OA knee by orthopedic specialists, $18-75 \mathrm{y}$ old, had moderate pain when they did not use analgesic (pain score $\geq 4$ with $0-10$ scale), body mass index (BMI) $\leq 39 \mathrm{~kg} / \mathrm{m}^{2}$, and agreed to follow the study by signing an informed consent. The definition of knee $\mathrm{OA}$ in this study is $\mathrm{OA}$ that met clinical criteria and radiological criteria based on Indonesian Rheumatism Association [2].

Exclusion criteria were patient with malignancy; pregnant or using hormonal contraceptive; bleeding disorder or using anticoagulant, or aspirin with daily dose more than $325 \mathrm{mg}$; uncontrolled hypertension (diastolic $>95$ or systolic $>165$ ), heart failure, or unstable angina; liver and kidney disorder (creatinine clearance $\leq$ $30 \mathrm{ml} / \mathrm{min}$ that was calculated with Cockroft-Gault formula); psychiatric disorders, using antidepressants, anticonvulsants, antipsychotics, sedatives, or muscle relaxant; drug dependency, drug abuse, or alcohol abuse ( $\geq 3$ glasses/d); history of allergy with drug used in this study; reading, hearing, and speaking inability.

\section{Evaluation of pain outcome}

Pain intensity was measured by a combination of Wong Backer Face Rating Scale (WBFPRS) and numeric rating scale (NRS) tools (fig. 1).
Patients were asked to circle one number between 0 and 10 that was the most appropriate to describe the intensity of their pain. Pain intensity was assessed at baseline and every week until the $4^{\text {th }} \mathrm{w}$. The area under the curve (AUC) of pain intensity on each subject was calculated up to $4 \mathrm{w}$ of observation using trapezoidal rule.

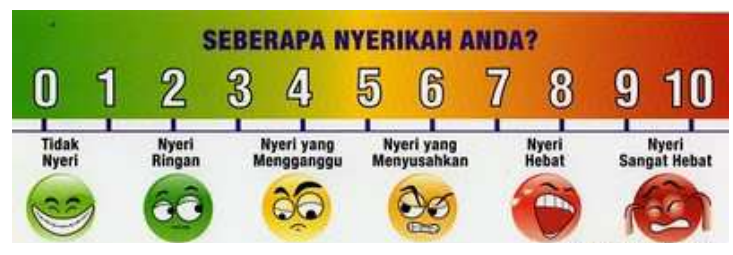

Fig. 1: Combination of WBFPRS and NRS tools

\section{Statistical analysis}

Data were analyzed with per protocol method. Normality test was analyzed with Shapiro-Wilk test. Data followed a normal curve if $p>0.05$. Homogeneity test was done by Levene's test. Data were homogeneous if $p>0.05$. Pain intensity was analyzed using the following method.

1. Paired-sample t-test or Willcoxon signed rank test was used to compare the efficacy of each group with baseline.

2. Independent-samples t-test or Mann-Whitney $\mathrm{U}$ test was used to compare the efficacy between the group receiving combination of diacerein and meloxicam, and meloxicam alone

For all test, data between different groups were significant if $p<0.05$

\section{RESULTS}

A total 68 subject were included in this study. Six subjects were excluded as they used others analgesics, had low compliance, experienced adverse drug reaction (ADR) that could not be tolerated, consumed other $\mathrm{OA}$ drug, and experienced getting worse pain. The remaining 62 patients completed the study and included in the analysis (fig. 2.)

Table 1: Demographic and clinical characteristics of participant

\begin{tabular}{|c|c|c|c|c|c|c|c|c|c|}
\hline \multirow{3}{*}{$\begin{array}{l}\text { No } \\
1\end{array}$} & \multicolumn{2}{|c|}{ Patients characteristics } & \multicolumn{3}{|c|}{ Combination of diacerein dan meloxicam $(\mathrm{N}=30)$} & \multicolumn{3}{|c|}{$\begin{array}{l}\text { Meloxicam alone } \\
(\mathrm{N}=32)\end{array}$} & \multirow{2}{*}{$\begin{array}{l}\mathbf{p} \\
1.00\end{array}$} \\
\hline & Gender & Female $\Sigma(\%)$ & $24(80.0 \%)$ & & & $25(7$ & & & \\
\hline & & Male $\Sigma(\%)$ & $6(20.0 \%)$ & & & $7(21$ & & & \\
\hline \multirow[t]{3}{*}{2} & Age & $\geq 60 y$ & $16(53.3 \%)$ & & & $18(5$ & & & 1.000 \\
\hline & & $<60 \mathrm{y}$ & $14(46.7 \%)$ & & & $14(4$ & & & \\
\hline & & mean $\pm S D(y)$ & 61.13 & \pm & 8.53 & 60.41 & \pm & 7.69 & 0.860 \\
\hline \multirow[t]{3}{*}{3} & BMI & Normal weight $\Sigma(\%)$ & $11(36.7 \%)$ & & & $6(18$ & & & 0.136 \\
\hline & & Overweight $\Sigma(\%)$ & $13(43.4 \%)$ & & & $13(4$ & & & \\
\hline & & Obese $\Sigma(\%)$ & $6(20.0 \%)$ & & & $13(40$ & & & \\
\hline 4 & Pain intensity & mean $\pm S D$ & 5.93 & \pm & 1.51 & 6.19 & \pm & 1.42 & 0.498 \\
\hline \multirow[t]{4}{*}{5} & WOMAC score & Pain (mean \pm SD) & 8.07 & \pm & 3.42 & 8.81 & \pm & 3.04 & 0.660 \\
\hline & & Stiffness (mean $\pm S D$ ) & 3.90 & \pm & 2.20 & 4.06 & \pm & 1.70 & 0.971 \\
\hline & & Physical function (mean $\pm S D$ ) & 31.70 & \pm & 11.74 & 34.34 & \pm & 10.15 & 0.346 \\
\hline & & Total $($ mean \pm SD) & 43.67 & \pm & 15.63 & 47.22 & \pm & 13.15 & 0.339 \\
\hline \multirow[t]{2}{*}{6} & Menopausal status & Menopause $\Sigma(\%)$ & $20(83.3 \%)$ & & & $24(9$ & & & 0.189 \\
\hline & & Not menopause $\Sigma(\%)$ & $4(16.7 \%)$ & & & $1(4.0$ & & & \\
\hline \multirow[t]{4}{*}{7} & OA grade & $1 \Sigma(\%)$ & $2(6.67 \%)$ & & & $0(0.0$ & & & 0.212 \\
\hline & & $2 \Sigma(\%)$ & $8(26.7 \%)$ & & & $19(5$ & $\%)$ & & \\
\hline & & $3 \Sigma(\%)$ & $16(53.3 \%)$ & & & $8(25$ & & & \\
\hline & & $4 \Sigma(\%)$ & $4(13.3 \%)$ & & & $5(15$ & & & \\
\hline \multirow[t]{3}{*}{8} & Duration of $\mathrm{OA}$ & $\geq 5$ y $\Sigma(\%)$ & $2(6.7 \%)$ & & & $1(3.1$ & & & 0.607 \\
\hline & & $<5$ y $\Sigma(\%)$ & $28(93.3 \%)$ & & & $31(9$ & & & \\
\hline & & mean $\pm S D$ (years) & 1.13 & \pm & 1.80 & 0.75 & \pm & 1.92 & 0.089 \\
\hline \multirow[t]{2}{*}{9.} & Involved joints & Unilateral & $15(50.0 \%)$ & & & $12(3$ & & & 0.462 \\
\hline & & Bilateral & $15(50.0 \%)$ & & & 206 & $\%)$ & & \\
\hline
\end{tabular}

$\mathrm{N}$ : sample size, BMI: body mass index (normal weight $\geq 18 \mathrm{~kg} / \mathrm{m}^{2}$ and $<25 \mathrm{~kg} / \mathrm{m}^{2}$; overweight $\geq 25 \mathrm{~kg} / \mathrm{m}^{2}$ and $<30 \mathrm{~kg} / \mathrm{m}^{2} ;$ obese $\geq 30 \mathrm{~kg} / \mathrm{m} 2$ ), WOMAC: The Western Ontario and McMaster Universities Arthritis Index 


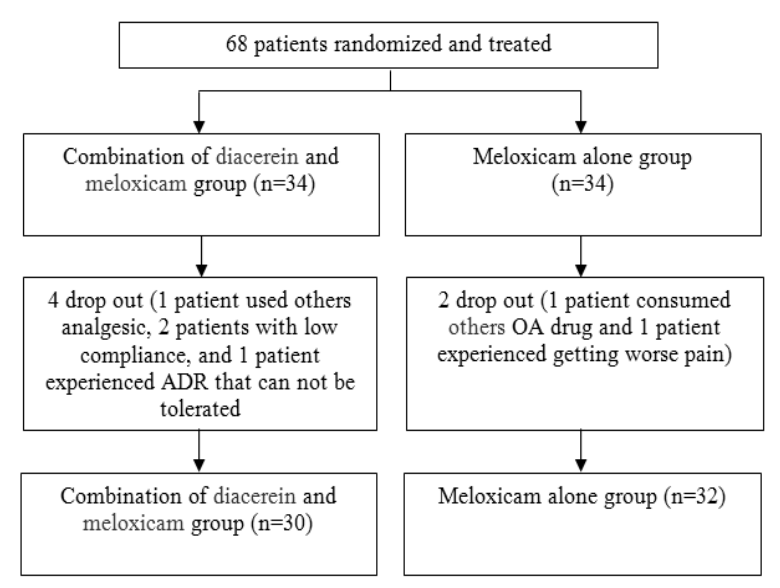

Fig. 2: Study design

The demographic and baseline clinical characteristics of patients were shown in table 1 . The two treatment groups were similar with regard to demographic data and baseline clinical characteristic.

\section{Pain outcome evaluation}

Pain score decreased significantly in all groups when compared to the baseline values of each group $(\mathrm{p}<0.05)$ after $4 \mathrm{w}$ therapies (table 2 ).
In the first week until $2^{\text {nd }} w$, the difference of pain score between the combination of meloxicam and diacerein, and meloxicam alone could not be seen. Those differences were seen at $3^{\text {rd }}$ weeks $(p<0.05)$. This difference was stable at the end of follow-up $\left(4^{\text {th }}\right.$ w). There was no significant difference in AUC of pain intensity (table 3).

\section{DISCUSSION}

This study was designed to assess the efficacy of combination diacerein and meloxicam, and meloxicam alone. In addition, this study was designed to compare the efficacy of combination diacerein and meloxicam, and meloxicam alone after $4 \mathrm{w}$ of therapy.

In this study, meloxicam $15 \mathrm{mg} / \mathrm{d}$ has proven effective to give a significant difference in the pain intensity between pre and post treatment after $4 \mathrm{w}$ of therapy. Efficacy of meloxicam in overcoming pain in OA was supported by RCT study by Lund $e t$ al. (2000). That study showed that meloxicam $15 \mathrm{mg} / \mathrm{d}$ was significantly more effective to reduce pain than placebo after $3 \mathrm{w}$ of treatment [24]. Randomized controlled trial study by Yocum et al. (2000) also showed the benefits of meloxicam $15 \mathrm{mg} / \mathrm{d}$ in patients with hip or knee OA compared to placebo. After $12 \mathrm{w}$ of therapy, there were differences in pain intensity when moved $(p<0.01)$ and pain at rest $(p \leq 0.001)$ [23]. The effect of meloxicam in reducing the pain intensity was caused by inhibition the cyclooxygenase (COX) enzyme. The COX-2 enzyme plays a role in the synthesis of prostaglandins, which were the mediators of pain [28].

Table 2: Statistical analysis results of pain intensity difference in pre and post treatment

\begin{tabular}{llllll}
\hline No & Groups & Pain intensity & N & mean \pm SD & Sig \\
\hline 1 & Combination of diacerein and meloxicam & Pre treatment & 30 & $5.93 \pm 1.507$ & $0.001^{*}$ \\
& & Post treatment & 30 & $3.03 \pm 1.098$ & \\
2 & Meloxicam alone & Pre treatment & 32 & $6.19 \pm 1.424$ & $0.001^{*}$ \\
& & Post treatment & 32 & $3.81 \pm 1.615$ & \\
\hline
\end{tabular}

N: sample size, Sig: significance, SD: Deviation standard, ${ }^{*}: \mathrm{p}<0.05$

Tabel 3: Statistical analysis results of pain intensity difference between combination of meloxicam and diacerein, and meloxicam alone

\begin{tabular}{|c|c|c|c|c|c|c|}
\hline \multirow[t]{2}{*}{ No } & \multirow[t]{2}{*}{ Time of follow-up } & \multicolumn{2}{|c|}{ Combination of diacerein dan meloxicam } & \multicolumn{2}{|c|}{ Meloxicam alone } & \multirow[t]{2}{*}{ Sig } \\
\hline & & mean \pm SD & CI 95\% & mean \pm SD & CI 95\% & \\
\hline 1. & Week 0 & $5.93 \pm 1.51$ & $5.37-6.50$ & $6.19 \pm 1.42$ & $5.67-6.70$ & 0.498 \\
\hline 2. & Week 1 & $4.83 \pm 1.60$ & $4.24-5.43$ & $5.34 \pm 1.52$ & $4.80-5.89$ & 0.093 \\
\hline 3. & Week 2 & $4.17 \pm 1.60$ & $3.57-4.76$ & $4.69 \pm 1.66$ & $4.09-5.28$ & 0.101 \\
\hline 4. & Week 3 & $3.37 \pm 1.25$ & $2.90-3.83$ & $4.19 \pm 1.67$ & $3.58-4.79$ & $0.031^{*}$ \\
\hline 5. & Week 4 & $3.03 \pm 1.10$ & $2.62-3.44$ & $3.81 \pm 1.62$ & $3.23-4.39$ & $0.035^{*}$ \\
\hline 6. & AUC & $16.85 \pm 5.22$ & $14.90-18.80$ & $19.22 \pm 5.97$ & $17.0-21.37$ & 0.064 \\
\hline
\end{tabular}

SD: Deviation standard, CI 95\%: Confident Interval 95\%, *: p<0.05

In this study, the combination of meloxicam and diacerein were significantly effective to reduce pain intensity after $4 \mathrm{w}$. There were no studies that accessed the efficacy of the combination of meloxicam and diacerein. However, there was a similar study conducted by Gupta et al. (2012). In that study, $50 \mathrm{mg}$ diacerein and other NSAIDs (diclofenac $75 \mathrm{mg} / \mathrm{d}$ ), showed significantly different pain scores compared with baseline (after $16 \mathrm{w}$ of therapy) [29]. Randomized controlled trial studies by Shafshak et al. (2012) showed administration diacerein $(100 \mathrm{mg} / \mathrm{d})$ and diclofenac giving the difference of pain intensity in the pre and post treatment, both at $1 \mathrm{mo}(\mathrm{p}=0.033)$ and $2 \mathrm{mo}(\mathrm{p}=0.001)$ therapy [30]. A significant reduction effect in pain intensity after $4 \mathrm{w}$ follow-up in this study was supported by the results of the other literature, which said that effects of diacerein appear 2-4 w after therapy, and were significant after 4-8 w [20]. Meloxicam reaches significant effects as an analgesic in $2^{\text {nd }-4^{\text {th }}} \mathrm{w}$ [27].

Diacerein therapeutic effect on OA based on its ability to inhibit pain and also its affect on the structural components of the joint [15].
Diacerein activities were caused by its ability to inhibit IL-1. In the chronic inflammatory process, such as the $\mathrm{OA}$, cells were under pressure and produced cytokines such as IL-1, IL-6, tumor necrosis factor- $\alpha$ (TNF- $\alpha$ ) which can cause damage to cells and phospholipids membrane release [14]. In structural components, IL-1 plays an important role in cartilage degradation [16].

When it is linked to the response to pain, mechanism of action of IL$1 \beta$ able can up-regulate of pro-nociceptive mediators, such as nerve growth factor (NGF), which was known as a neurotrophic factor that played an important role in the process of pain. Interleukin $1 \beta$ can signal through a signal cascade that leads to the release and/or activation of nociceptive molecules such as prostaglandins, IL-6, substance $P$, and matrix metalloproteinase 9 (MMP 9). The action of IL-1 $\beta$ may also occur directly on nociceptors. The receptor for IL-1 is expressed in sensory neurons. Interleukin-1 $\beta$ can modulate neuronal accessibility to affect neuronal receptors such as sodium channels, gamma-aminobutyric acid (GABA), and n-methyl-daspartate (NMDA) receptors [31]. With a complex mechanism, 
diacerein can reduce the intensity of pain and prevents further cartilage damage.

When it was compared with meloxicam alone, the combination of meloxicam and diacerein showed no significant difference in pain intensity at $1^{\text {st }}$ and $2^{\text {nd }} \mathrm{w}$. It could be caused by the onset of diacerein which was achieved at $2^{\text {nd }}$ to $4^{\text {th }} \mathrm{w}$ after administration. The difference in pain intensity on both of groups can be observed at the $3^{\text {rd }}$ week $4^{\text {th }}$ weeks. Meloxicam alone group had greater pain intensity than its combination with diacerein.

When they were compared using AUC parameters, the combination of meloxicam and diacerein and meloxicam alone did not show a significant difference. Area under the curve data is the result of merging the intensity of pain from time to time. Pain intensity data can be transformed to the AUC to access the benefits of analgesic [32]. Compared with measurements at the end of study (EOS), the results of trials using the AUC provide smaller effect estimation but better precision. Area under the curve values gives the possibility to maintain the distinction treatment group by calculating the exact onset and offset of action of the drug. Trial with the rapid acting drug showed that AUC was more sensitive than EOS to detect treatment differences [33]. Analysis of the AUC was more stable and sensitive to see the interpatient difference than other measurements. Area under the curve described the cumulative response of an intervention, but did not provide information about the onset of analgesic effect [34].

Despite they have the different working mechanism and can support each other, the addition of diacerein to meloxicam therapy provided no significant difference in AUC of pain intensity. Several other studies supported the insignificant outcomes of pain intensity between the combination of diacerein and meloxicam with meloxicam alone. The results of this research were supported by a similar study conducted by Gupta et al. (2012). In that study, diacerein $50 \mathrm{mg}$ in combination with other NSAIDs (diclofenac 75 $\mathrm{mg}$ ) per day has shown significant differences in pain scores after 16 $\mathrm{w}$ of therapy compared with NSAIDs alone. That study did not explain the differences in pain scores over time between the combination group and single group. So, it was not known when these differences began to appear [29]. If it was assumed differences emerged at week $16^{\text {th }}$, the longer observation was needed in order to see the effect of the combination of meloxicam and diacerein.

Randomized controlled trial study by Shafshak et al. (2012), in patients receiving diacerein $100 \mathrm{mg} / \mathrm{d}$ for $2 \mathrm{mo}$ vs diclofenac vs diacerein, found that in all three groups, there were no significant difference in pain intensity, both at $1 \mathrm{mo}(\mathrm{p}=0.493)$ and $2 \mathrm{mo}(\mathrm{p}=$ 0.325) therapy [30]. Another study by Singh et al. (2012) also showed the comparison of addition NSAID (diclofenac) in patients with knee $\mathrm{OA}$ who consumed diacerein. The study was conducted for $3 \mathrm{mo}$. The combination group used diacerein $50 \mathrm{mg} / \mathrm{d}$ in the first month, $2 \times 50 \mathrm{mg} / \mathrm{d}$ in $2^{\text {nd }}$ and $3^{\text {rd }}$ and sustained release diclofenac $75 \mathrm{mg} / \mathrm{d}$ from $1^{\text {st }}$ to $3^{\text {rd }}$ mo. Comparison group only used sustained release diclofenac $75 \mathrm{mg} / \mathrm{d}$. After $3 \mathrm{mo}$, administration of diacerein and diclofenac showed a significant difference in pain intensity compared to diclofenac alone [35]. The difference above was appeared in a longer time (3 mo) compared to our study. That study did not explain about differences in pain scores over time, between the combination group and single froup, so it was unknown when these differences were begun. If it was assumed in Singh et al. study that differences were shown at the $3^{\text {rd }}$ mo (week 12), we needed longer observation in order to see the different between the combination of diacerein and meloxicam, and meloxicam alone. In addition, that study used different dose every month $(50 \mathrm{mg} / \mathrm{d}$ of diacerein in the first month, followed by $100 \mathrm{mg} / \mathrm{d}$ in the next $2 \mathrm{mo}$ ). This dose differences could affect the outcome differences.

The difference of efficacy that was shown at $3^{\text {rd }}$ and $4^{\text {th }} \mathrm{w}$ indicated that combination of meloxicam and diacerein had the potential benefits in the treatment of OA. Effect of diacerein was begun at $2^{\text {nd }}$ to $4^{\text {th }} \mathrm{w}$ and significant at $4^{\text {th }} 8^{\text {th }} \mathrm{w}$ [14]. Thus, we need longer observation up to $8 \mathrm{w}$ in order to see the differences in the AUC of pain intensity. The differences in pain intensity between 2 groups become insignificant can be caused by small sample size, so we required the addition of large samples. In addition, different baseline characteristics among study could influence the results, such as gender, BMI, and duration of suffering from OA.

There were differences in the proportion of men and women in the study conducted by Gupta et al. (2012) with our study. Our study was dominated by women $(78.1 \%-80.00 \%)$, whereas in the study of Gupta et al., the proportion between male and female was comparable (male: female $=2: 3$ ). Gender was known affecting response to pain experienced. The study that was conducted by Tonelli et al. (2011) showed that women had a greater pain intensity than men in patients with osteoarthritis $(p=0.04)$ [36]. Differences in BMI also can contribute to pain intensity difference in OA patients. A study by Oyeyemi et al. (2013) showed that BMI influenced the effectiveness of knee OA treatment [37]. The significant differences in pain intensity between the normal weight and overweight $(p=$ $0.016)$ patient and between normal weight and obese patient $(\mathrm{p}=$ 0.005 ) was found.

\section{CONCLUSION}

Combination therapy of diacerein and meloxicam was more effective than meloxicam alone. A significant effect of a combination therapy of diacerein and meloxicam occurred at $3^{\text {rd }} \mathrm{w}$. The prolong study in order to get the differences in AUC pain score are needed. In addition, the cost-effectiveness analysis was needed to see the benefit of that combination compared with the single therapy.

\section{ACKNOWLEDGEMENT}

The authors thank all of the subjects for participating in this study. We also acknowledge to orthopedic specialists in orthopedic departement of RSUD Dr. Mohammad Soewandhie Surabaya (dr. Bimo Sasono, dr. Carlos Supriyantono Binti, Sp. OT and dr. Gede Chandra Purnama Yudha, Sp. OT.) that helped the author during data collecting.

\section{AUTHOR CONTRIBUTION}

Author, Ni Made Oka Dwicandra, made substantial contributions to conception and design, acquisition of data, and analysis and interpretation of data. Co author, Antonious Adji Prayitno Setiadi, participated in drafting the article and revising it critically for important intellectual content.

\section{AFFILIATION}

\section{Ni Made Oka Dwicandra}

Pharmacy Department, Institute of Health Sciences Medika Persada Bali, Denpasar, Bali, Indonesia

Antonious Adji Prayitno Setiadi

Departement of Clinical Pharmacy, Pharmacy Faculty, University of Surabaya, Surabaya, Jawa Timur, Indonesia

\section{LIST OF ABBREVIATION}

AUC: area under the curve, BMI: body mass index, ECM: extracellular matrix, EOS: end of study, GABA: gamma-aminobutyric acid, IL: interleukin, MMP: matrix metalloproteinase, NGF: nerve growth factor, NMDA: n-methyl-d-aspartate, NRS: numeric rating scale, NSAID: non steroidal anti-inflammatory drugs, OA: osteoarthritis, RCT: randomized controlled trial, RSUD: rumah sakit umum daerah, TNF: tumor necrosis factor, WBFRS: wong backer faces rating scale, WHO: world health organization

\section{FUNDING}

No specific funding was received for this study

\section{CONFLICTS OF INTERESTS}

All authors have none to declare

\section{REFERENCES}

1. Alldredge BK, Affairs A, Francisco S, Corelli RL, Ernst ME, City I, et al. Koda-Kimble and Young's Applied Therapeutic: The Clinical Use of Drug. $10^{\text {th }}$ ed. Philadelphia: Lippincot Williams and Wilkins; 2013. 
2. The Indonesian Rheumatism Association. Diagnosis dan Penatalaksanaan Osteoartritis. Jakarta: The Indonesian Rheumatism Association; 2014.

3. Jena M, Mishra S, Pradhan S, Jena S, Mishra SS. Chronic pain, its management and psychological issues: a review. Asian J Pharm Clin Res 2015;8:42-7.

4. Łastowiecka E, Bugajska J, Najmiec A, Rell-Bakalarska M, Bownik I, Jedryka-Góral A. Occupational work and quality of life in osteoarthritis patients. Rheumatol Int 2006;27:131-9.

5. Tak S, Laffrey S. Life satisfaction and its correlates in older women with osteoarthritis. Orthopaedic Nursing 2003;22:182-9.

6. Conaghan P, Rannou F, Arden N, Everett SV, Balshaw R, Peloso $\mathrm{PM}$, et al. Inadequate pain relief (IPR) in knee osteoarthritis: what does it look like? a European survey of osteoarthritis real world therapies (SORT). Osteoarthritis and Cartilage J 2012;20:S178.

7. Jameson K, Balshaw R, Phillips C, Martin GR, Everett SV, Watson DJ, et al. PMS59 inadequate pain relief in knee osteoarthritis and patient reported outcomes: a survey of osteoarthritis real world therapies (SORT) in the United Kingdom. Value Health 2011;14:A313.

8. Conaghan PG, Peloso PM, Everett SV, Rajagopalan S, Black CM, Mavros $\mathrm{P}$, et al. Inadequate pain relief and large functional loss among patients with knee osteoarthritis: evidence from a prospective multinational longitudinal study of osteoarthritis real-world therapies. Rheumatology (Oxford) 2015;54:270-7.

9. Mercadante S, Casuccio A, Agnello A, Pumo S, Kargar J, Garofalo S. Analgesic effects of nonsteroidal anti-inflammatory drugs in cancer pain due to somatic or visceral mechanisms. J Pain Symptom Manage 1999;17:351-6.

10. Frakes EP, Risser RC, Ball TD, Hochberg MC, Wohlreich MM. Duloxetine added to oral nonsteroidal anti-inflammatory drugs for treatment of knee pain due to osteoarthritis: results of a randomized, double-blind, placebo-controlled trial. Curr Med Res Opin 2011;27:2361-72.

11. Ohtori S, Inoue G, Orita S, Takaso M, Eguchi Y, Ochiai N. Efficacy of combination of meloxicam and pregabalin for pain in knee osteoarthritis. Yonsei Med J 2013;54:1253-8.

12. Colville-Nash P, Willoughby D. COX-1, COX-2 and articular joint disease: a role for chondroprotective agents. Biorheology 2002;39:171-9.

13. Fidelix T, Macedo C, Maxwell L, Fernandes Moça Trevisani V. Diacerein for osteoarthritis. Cochrane Database of Systematic Reviews; 2014

14. Medhi B. Diacerein: a new disease modulating agent in osteoarthritis. Indian J Physical Med Rehabilitation 2007;18:48-52.

15. Mahajan A, Singh K, Tandon VR, Kumar S, Kumar H. Diacerein: a new symptomatic slow acting drug for Osteoarthritis. JK Sci 2006;8:173-5.

16. Lee AS, Ellman MB, Yan D, Kroin JS, Cole BJ, van Wijnen AJ, et al. A current review of molecular mechanisms regarding osteoarthritis and pain. Gene 2013;527:440-7.

17. Kongtharvonskul J, Anothaisintawee T, McEvoy M, Attia J, Woratanarat P, Thakkinstian A. Efficacy and safety of glucosamine, diacerein, and NSAIDs in osteoarthritis knee: a systematic review and network meta-analysis. Eur J Med Res 2015;20:1-11.

18. Rintelen B, Neumann K, Leeb B. A meta-analysis of controlled clinical studies with diacerein in the treatment of osteoarthritis. Arch Intern Med 2006;166:1889-906.

19. Bartels EM, Bliddal H, Schøndorff PK, Altman RD, Zhang W, Christensen R. Symptomatic efficacy and safety of diacerein in the treatment of osteoarthritis: a meta-analysis of randomized placebo-controlled trials. Osteoarthritis Cartilage 2010;18:289-96.

20. Pelletier J, Yaron M, Haraoui B, Cohen P, Nahir MA, Choquette $\mathrm{D}$, et al. Efficacy and safety of diacerein in osteoarthritis of the knee. Arthritis Rheum 2000;43:2339-48.
21. Pavelka K, Trc T, Karpas K, Vítek P, Sedlácková $M$, Vlasáková V, et al. The efficacy and safety of diacerein in the treatment of painful osteoarthritis of the knee: a randomized, multicenter, double-blind, placebo-controlled study with primary end points at two months after the end of a three-month treatment period. Arthritis Rheum 2007;56:4055-64.

22. Mirunalini R, Chandrasekaran M, Manimekalai K. Efficacy of chondroitin sulfate with glucosamine versus diacerein in grade ii and iii osteoarthritis knee: a randomized comparative study. Asian J Pharm Clin Res 2015;8:42-4.

23. Yocum D, Fleischmann R, Dalgin P, Caldwell J, Hall D, Roszko P. Safety and efficacy of meloxicam in the treatment of osteoarthritis a 12-week, double-blind, multiple-dose, placebocontrolled trial. Arch Intern Med 2000;160:2947-54.

24. Lund B, Distel M, Bluhmki E. A double-blind, randomized, placebo-controlled study of efficacy and tolerance of meloxicam treatment in patients with osteoarthritis of the knee. Scand J Rheumatol 1998;27:32-7.

25. Goei HS, Lund B, Distel M, Bluhmki E. A double-blind, randomized trial to compare meloxicam $15 \mathrm{mg}$ with diclofenac $100 \mathrm{mg}$ in the treatment of osteoarthritis of the knee. Osteoarthritis Cartilage 1997;5:283-8.

26. Zeidler H, Kaltwasser J, Leonard J, Kohlmann T, Sigmund R, Degner F, et al. Prescription and tolerability of meloxicam in dayto-day practice: postmarketing observational cohort study of 13,307 patients in Germany. J Clin Rheumatol 2002;8:305-15.

27. Tacca M Del, Colucci R, Fornai M, Blandizzi C. Efficacy and tolerability of meloxicam, a COX-2 preferential nonsteroidal anti-inflammatory drug. Clin Drug Inves 2002;11:1-22.

28. Dipiro J, Talbert R, Yee G, Matzke G, Wells B, Posey L. Pharmacotherapy: pathophysiologic approach. $7^{\text {th }}$ ed. USA: The McGraw-Hill Companies, Inc; 2008.

29. Gupta N, Datta S. Efficacy and safety of diacerein and diclofenac in knee osteoarthritis in Indian patients-a prospective randomized open label study. J Biomed Sci 2012;1:1-14.

30. Shafshak TS, Shaheen EM, Hussein N, Hafez AA. The efficacy of diacerein with and without diclofenac sodium on knee pain severity and walking time in patients with knee osteoarthritis. Indian J Sci Res 2014;3:2012-5.

31. Rena K, Torres R. Role of interleukin- $1 \beta$ during pain and inflammation. Brain Res Rev 2011;60:57-64.

32. Lee CJ, Lee LH, Wu CL, Lee BR, Chen ML. Clinical trials of drug and biopharmaceuticals. USA: Taylor and Francis Group; 2006.

33. Pham B, Cranney A, Boers M, Verhoeven A, Wells G, Tugwell P. Validity of area-under-the-curve analysis to summarize effect in rheumatoid arthritis clinical trials. J Rheumatol 1999;26:712-6.

34. Schiff M. A rationale for the use of summary measurements for the assessment of the effects of rheumatoid arthritis therapies. Clin Ther 2003;25:993-1001.

35. Singh K, Sharma R, Rai J. Diacerein as adjuvant to diclofenac sodium in osteoarthritis knee. Int J Rheum Dis 2012;15:69-77.

36. Tonelli SM, Rakel BA, Cooper NA, Angstom WL, Sluka KA. Women with knee osteoarthritis have more pain and poorer function than men, but similar physical activity prior to total knee replacement. Biol Sex Differ 2011;2:1-12.

37. Oyeyemi AL. Body mass index, pain and function in individuals with knee osteoarthritis. Nigerian Med J 2013;54:230-5.

\section{How to cite this article}

- Ni Made Oka Dwicandra, Antonious Adji Prayitno Setiadi. Comparison of pain score in osteoarthritis patients treated with a combination of diacerein and meloxicam and meloxicam alone. Int J Pharm Pharm Sci 2017;9(6):69-73. 